Revta brasil. Bot., São Paulo,V.24, n.4 (suplemento), p.595-602, dez. 2001

\title{
Histological changes in banana explants, cv. Nanicão (Musa spp., Group AAA), submitted to different auxins for induction of somatic embryogenesis
}

\author{
SILVIA BALBÃO FILIPPI ${ }^{1}$, BEATRIZ APPEZZATO-DA-GLÓRIA ${ }^{2}$ e ADRIANA PINHEIRO \\ MARTINELLI RODRIGUEZ ${ }^{1,3}$
}

(received: September 6, 2000; accepted: August 1, 2001)

\begin{abstract}
Histological changes in banana explants, cv. Nanicão (Musa spp. Group AAA), submitted to different auxins for induction of somatic embryogenesis). The present work analyzes the behavior of banana explants, cv. Nanicão (Musa spp. Group AAA) regarding somatic embryogenesis induction treatments with several auxins. Longitudinal segments of shoot meristematic apices of micropropagated banana plantlets cultivated and rooted in vitro were introduced in culture medium containing dicamba, picloram, 2,4-D or NAA in different concentrations. Explant samples were collected at 0, 7 and 10 days and prepared for light microscopy. Histological sections were used for comparison of the histological changes occurring after induction treatment with different auxins. Embryogenic response was observed only in treatments with picloram or dicamba, with distinct embryogenic regions observed at 14 and 21 days in culture, respectively. Histological sections of embryogenic regions of the explant at 26 days in culture revealed the formation of meristematic regions, structures with multiple root meristems, and somatic embryos at early globular stages. Embryo-like structures morphologically similar to Musa balbisiana zygotic embryos were sectioned and showed a lack of apical meristems and absence of procambial differentiation. These results indicate the induction of non-functional somatic embryos and the need for more studies on developmental aspects and maturation treatments for optimization of the process.
\end{abstract}

RESUMO - (Alterações histológicas em explantes de bananeira, cv. Nanicão (Musa spp. Grupo AAA) submetidos a diferentes auxinas para indução de embriogênese somática). O presente trabalho analisa o comportamento de explantes de bananeira 'Nanicão' (Musa spp. Grupo AAA) a tratamentos de indução com diferentes auxinas, visando à obtenção de embriogênese somática. Segmentos longitudinais de ápices meristemáticos caulinares de plântulas de bananeira micropropagadas e enraizadas in vitro foram introduzidos em meio de cultura contendo dicamba, picloram, 2,4-D ou NAA. Amostras dos explantes aos 0,7 e 10 dias foram coletadas e preparadas para microscopia óptica. Cortes histológicos foram realizados nesses explantes, comparando-se as alterações observadas após os tratamentos com diferentes auxinas. Respostas embriogênicas foram observadas somente nos tratamentos com picloram e dicamba, sendo possível a observação visual de regiões embriogênicas aos 14 e 21 dias de cultivo, respectivamente. Cortes histológicos de regiões embriogênicas dos explantes, aos 26 dias, revelaram a formação de regiões meristemáticas compostas aparentemente por múltiplos meristemas radiculares e embriões nas fases iniciais do estágio globular. Cortes histológicos de estruturas morfologicamente semelhantes a embriões zigóticos de Musa balbisiana revelaram ausência dos meristemas apicais e não diferenciação procambial. Os resultados indicam a indução de embriões somáticos não-funcionais e, consequentemente, a necessidade de maiores estudos visando otimizar o processo de desenvolvimento e maturação dos embriões somáticos.

Key words - Histology, somatic embryos, dicamba, picloram, banana

\section{Introduction}

Polyploidy and sterility, characteristics of commercial cultivars of Musa spp., are disadvantageous for the inclusion of banana

1. Universidade de São Paulo, Centro de Energia Nuclear na Agricultura, Av. Centenário 303, 13400-970 Piracicaba, SP, Brasil.

2. Universidade de São Paulo, Escola Superior de Agricultura Luiz de Queiroz, Departamento de Ciências Biológicas, Av. Pádua Dias, 11, 13418-970 Piracicaba, SP, Brasil.

3. Autor para correspondência: adriana@cena.usp.br cultivars in breeding programs (Novak et al. 1989). Somatic embryogenesis associated with genetic manipulation techniques is of great interest for the production of new cultivars through plant transformation. Banana plants are threatened by many diseases and pests and because of the difficulties for conventional breeding there are high expectations on the use of biotechnology as a tool for breeding programs. However, an efficient somatic embryogenic protocol must be developed, with a high rate of embryo conversion.

Somatic embryogenesis is an in vitro morphogenic response in which embryos are induced from somatic cells, with further 
regeneration of plants (Williams \& Maheswaran 1986). In general, the process follows three main stages: induction of embryogenic callus, development and maturation of somatic embryos, and conversion of somatic embryos into plants. The induction stage is considered of great importance for obtaining well-formed somatic embryos, contributing to the subsequent stages of development, i.e. maturation and conversion into plants. The choice of auxin is very important in the induction process and can affect the frequency and morphology of somatic embryos (Lazzeri et al. 1987, Levi \& Sink 1991, Rodriguez \& Wetzstein 1994, 1998).

Somatic embryogenesis of banana cultivars of different groups has been successfully achieved (Novak et al. 1989, Dedh'a et al. 1991, Côte et al. 1996, Escalant et al. 1994, Grapin et al. 1996), however, the conversion into plants is frequently low, thus limiting its association with genetic transformation techniques. The characterization of the different stages of the embryogenic process can help to detect possible limiting steps as well as to locate the embryogenic regions in the explant. This can assist in the definition of strategies for genetic manipulation of the material.

The present work aims to evaluate the histological changes which occur during induction of somatic embryogenesis in longitudinal sections of vegetative shoot apices of banana plantlets, $\mathrm{cv}$. Nanicão (AAA group) by different auxins.

\section{Material and methods}

Somatic embryogenesis induction - Micropropagated banana plantlets (Musa spp., cv. Nanicão), 7- to 10-mm-thick (at the base) were collected and longitudinal segments of the apical region were prepared as explants. These consisted of the shoot apical meristem surrounded by leaf bases and part of the rhizome tissue, approximately 5-10 $\mathrm{mm}$ long, 5-7 mm in width and 1-2 mm thickness. Explants were introduced in Petri dishes containing MS (Murashige \& Skoog 1962) medium supplemented with either one of the following auxins: dicamba $(10 \mu \mathrm{M})$, picloram $(5$ or $10 \mu \mathrm{M})$, naphtaleneacetic acid (NAA) (15 or $20 \mu \mathrm{M}), 2,4$-dichlorophenoxiacetic acid (2,4-D) (15 or $20 \mu \mathrm{M}$ ) or absence of auxin. Media $\mathrm{pH}$ was 5.8 prior to autoclaving at $121{ }^{\circ} \mathrm{C}$, for $20 \mathrm{~min}$. Each treatment consisted of ten Petri dishes, each with six explants. After four weeks, the embryogenic cultures were transferred to the same basal medium devoid of auxin, for embryo development. All cultures were maintained in the darkness at $26 \pm 2{ }^{\circ} \mathrm{C}$.
Histological analysis - Explant samples were collected at zero, seven and ten days in induction medium. At day 26, samples from embryogenic regions formed in treatments with dicamba $(10 \mu \mathrm{M})$ and picloram $(5$ or $10 \mu \mathrm{M})$ were also collected. Somatic embryos formed in the embryogenic regions were also sampled for histological comparison. All samples were fixed according to Rodriguez \& Wetzstein (1998), in paraformaldehyde (3\%, $\mathrm{w} / \mathrm{v})$ and glutaraldehyde $(2 \% \mathrm{v} / \mathrm{v})$ in cacodylate buffer $(0.2 \mathrm{M}$, $\mathrm{pH}$ 7.2) under refrigeration, with the first hour under low vacuum. Fixed tissues were slowly dehydrated at room temperature in a series of ethanol (35-100\%), followed by infiltration at $4{ }^{\circ} \mathrm{C}$ overnight, in etanol:infiltration medium (Historesin, Leica) (1:1). Infiltration was completed with infiltration medium $(100 \%)$ for $24 \mathrm{~h}$ or until the samples appeared translucid and sank to the bottom of the flask. Polymerization was done at room temperature for 24 to $48 \mathrm{~h}$. Serial sections $(5 \mu \mathrm{M})$ were prepared in a rotary microtome (Leica RM-2155) with a tungsten-carbide knife, the sections floated in water drops, dried on a hot plate $\left(40{ }^{\circ} \mathrm{C}\right)$, and stained either in toluidine blue $(0.05 \%)$ or acid fuchsin $(0.1 \%)$, and counter stained with toluidine blue $(0.05 \%)$ (Feder \& O'Brien 1968).

\section{Results and Discussion}

Histological sections of the explants at the time of introduction in vitro showed cortical parenchyma surrounding the central cylinder region. This region was constituted by parenchyma tissue interspersed with vascular strands (figure 1). After seven days in culture, histological sections of explants cultivated in both NAA treatments showed absence of meristematic regions with tissue basically composed of parenchyma cells and vascular strands (figure 2), similar to the explant tissue before auxin treatment. At day seven, explants treated with 2,4D showed small meristematic regions, with mitotic activity mainly in the pericycle (figure 3 ). Treatment with picloram (figure 4) showed higher meristematic activity when compared to 2,4-Dtreated explants. After seven days in culture, the treatment showing the most intense meristematic response was $10 \mu \mathrm{M}$ dicamba (figures 5-6), with two types of response. In some areas of the pericycle, intense mitotic activity was characterized by the presence of small rapidly dividing cells, with large nucleus and reduced area of vacuoles (figure 5). In other areas of the pericycle, initial formation of globular proembyos could be observed (figure 6).

Evaluation of the explants at days 15 and 30 in induction medium confirmed the histological observations in the control and NAA treatments 

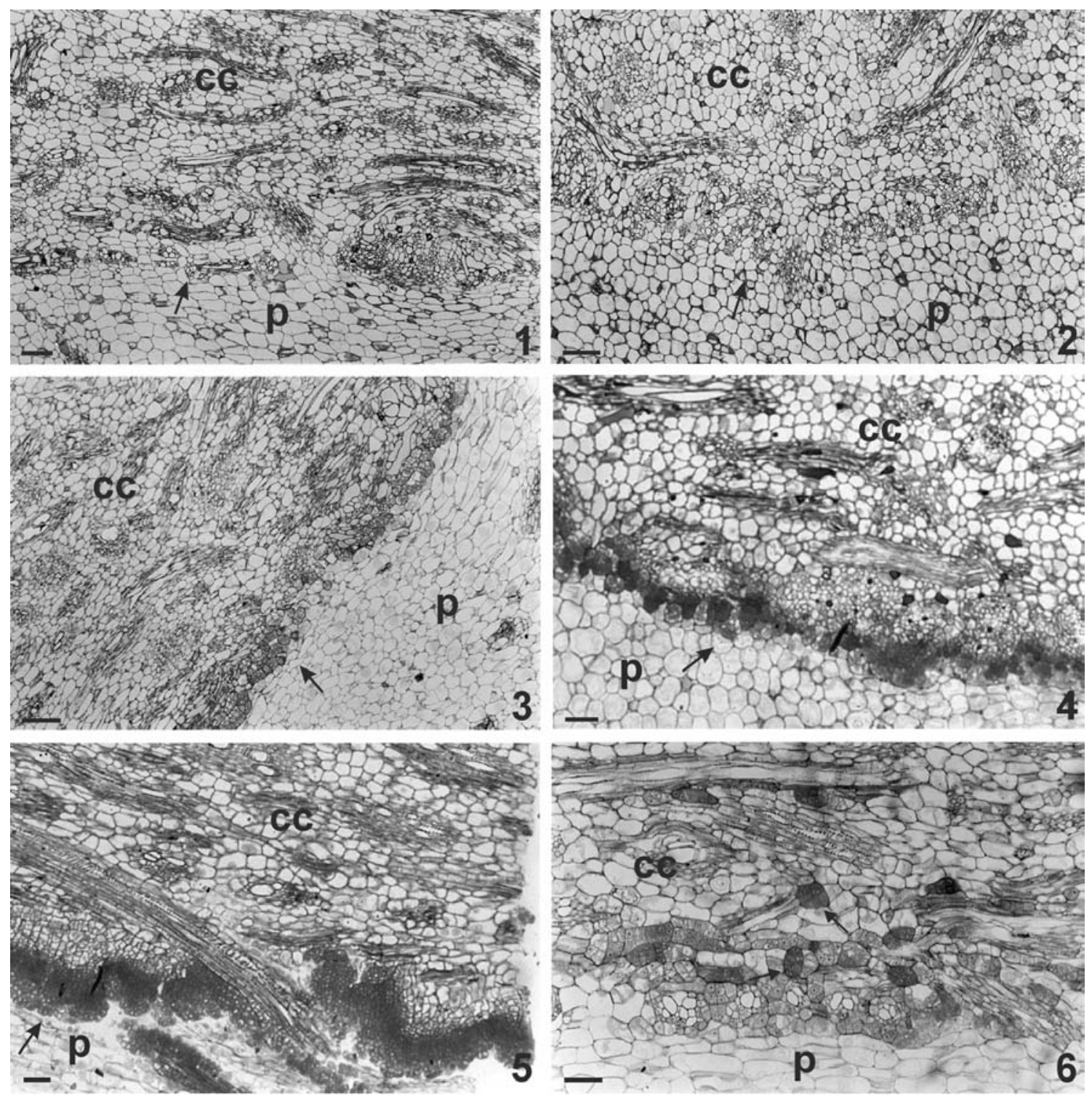

Figures 1-6. Longitudinal sections of vegetative apices of banana, cv. Nanicão, in MS medium containing different auxins for somatic embryo induction. 1. Explant at day 0 showing parenchyma tissue and vascular strands (arrow = pericycle region). 2-6. Explants after seven days in medium containing: 2. $20 \mu \mathrm{M}$ NAA, with absence of meristematic activity (arrow $=$ pericycle region). 3. $20 \mu \mathrm{M}$ 2,4-D, with little mitotic activity (arrow = pericycle region). $4.10 \mu \mathrm{M}$ picloram, with areas with more intense mitotic activity (arrow = pericycle region). $5.10 \mu \mathrm{M}$ dicamba, showing intense mitotic activity, characterized by the presence of small cells, dense cytoplasm and reduced vacuolization (arrow = pericycle region). 6. $10 \mu \mathrm{M}$ dicamba, showing embryogenic regions with initial formation of proembryos ( arrow $=$ proembryos $).(p=$ cortical parenchyma; $c c=$ central cylinder $)$. Bars $=200$ $\mu \mathrm{m}(1-3) ; 100 \mu \mathrm{m}(4-6)$.

(table 1). Culturing the explants (figure 7) in absence of auxin or the exposure to NAA treatments (15 and $20 \mu \mathrm{M}$ ) for 30 days was not efficient for embryogenic induction. In these treatments, the development of pre-existing shoot buds and roots (figure 8) occurred in approximately half of the explants (table 1).

Although the histological sections at day 7 showed initial stages of meristematic activity in 
Table 1. Banana shoot apex explant responses to auxin treatments after 15 and 30 days, cultured in the dark (cv. Nanicão, group AAA).

\begin{tabular}{|c|c|c|c|c|c|}
\hline \multirow[t]{2}{*}{ Auxins } & \multicolumn{3}{|c|}{ Embryogenic callus* } & \multicolumn{2}{|c|}{ Shoot buds and roots* (pre-existing) } \\
\hline & $\mu \mathrm{M}$ & 15 days & 30 days & 15 days & 30 days \\
\hline Absence & & 0.0 & 0.0 & 49.6 & 58.7 \\
\hline NAA & 15 & 0.0 & 0.0 & 46.0 & 56.4 \\
\hline NAA & 20 & 0.0 & 0.0 & 36.3 & 46.5 \\
\hline 2,4-D & 15 & 0.0 & 0.0 & 0.0 & 0.0 \\
\hline $2,4-\mathrm{D}$ & 20 & 0.0 & 0.0 & 0.0 & 0.0 \\
\hline Picloram & 5 & 65.7 & 100.0 & 0.0 & 0.0 \\
\hline Picloram & 10 & 59.0 & 100.0 & 0.0 & 0.0 \\
\hline Dicamba & 10 & 0.0 & 80.0 & 0.0 & 0.0 \\
\hline
\end{tabular}

* results are presented in percentage, considering 10 replications per treatment

explants cultivated in medium with 2,4-D, evaluations under the stereo microscope after 15 and 30 days did not show embryogenic activity (figures 9-10). Instead, intense oxidation was observed especially in the higher concentration, with high amounts of phenolic compounds in the medium. The initial meristematic activity observed in the 2,4-D-treated explants had apparently ceased. However, differently from NAA, the auxin 2,4-D in both concentrations was able to block the normal development of previously formed shoot buds and roots.

Embryogenic response was only obtained in explants cultured in picloram (figure 11) and dicamba (figure 12). These treatments differed mainly in the number of days for visual observation of the embryogenic regions, which occurred after 14 days in picloram, and 21 days in dicamba. This was in contrast to the observations made in histological sections at day 7 (figure 5), where explants in dicamba showed more intense meristematic regions. In this experiment, embryogenic structures in dicamba showed a decline in development, with partial oxidation after five weeks. This suggests that further studies are needed to define the optimal number of days in induction treatment.

The type of explant responded positively to embryogenesis induction, when cultured either in picloram or dicamba. In preliminary tests (data not shown), the thickness of the explants influenced the response. Thickness of approximately 1-2 $\mathrm{mm}$ gave best results, compared to thicker ones. Embryogenic response was more intense in the shoot meristem, leaf bases and central cylinder.
These regions retain more meristematic ability, which facilitates the onset of embryogenesis.

After 25 days in induction medium containing dicamba or picloram, globular structures developing from the embryogenic regions were observed with the aid of a stereo microscope. Histological sections at day 26 showed proembryos (figures 13-15) in different sizes and non-globular meristematic regions, mainly in the central cylinder (figure 13). Frequently, separation of cell walls surrounding the proembryos was observed (figure 15 ), indicating proembryo isolation. Other structures were also observed in culture, some showing the formation of multiple root primordia (figure 16), which could have had their origin in non-globular meristematic areas.

In subsequent stages, somatic embryos were observed developing from the embryogenic regions. These were morphologically similar to zygotic embryos of Musa balbisiana presented by McGahan (1961), with a larger area corresponding to the haustorium and a region with a smaller diameter where the embryonic axis differentiates. McGahan (1961) presented details of the zygotic embryo of M. balbisiana. All the embryo cells are densely packed with protein and lipid storage, with absence of starch. A distinct shoot apical meristem and the first leaf primordium are observed and a single procambial strand bifurcates several times through all the embryo extension. Although morphologically similar to the zygotic embryos, histological sections of the somatic embryos in this experiment (figure 17) revealed lack of histodifferentiation and absence of storage 

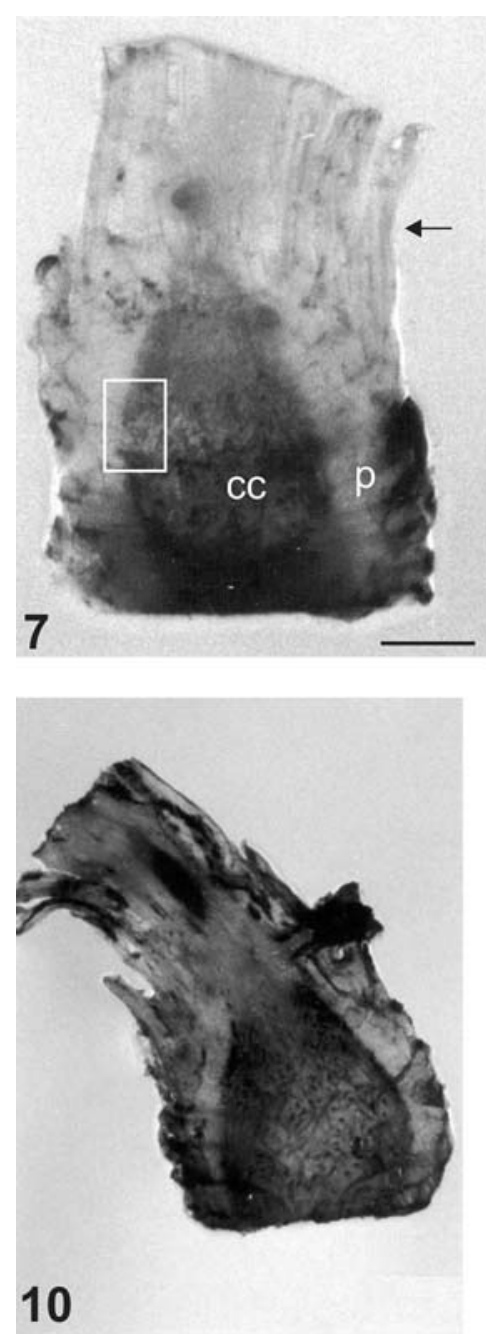
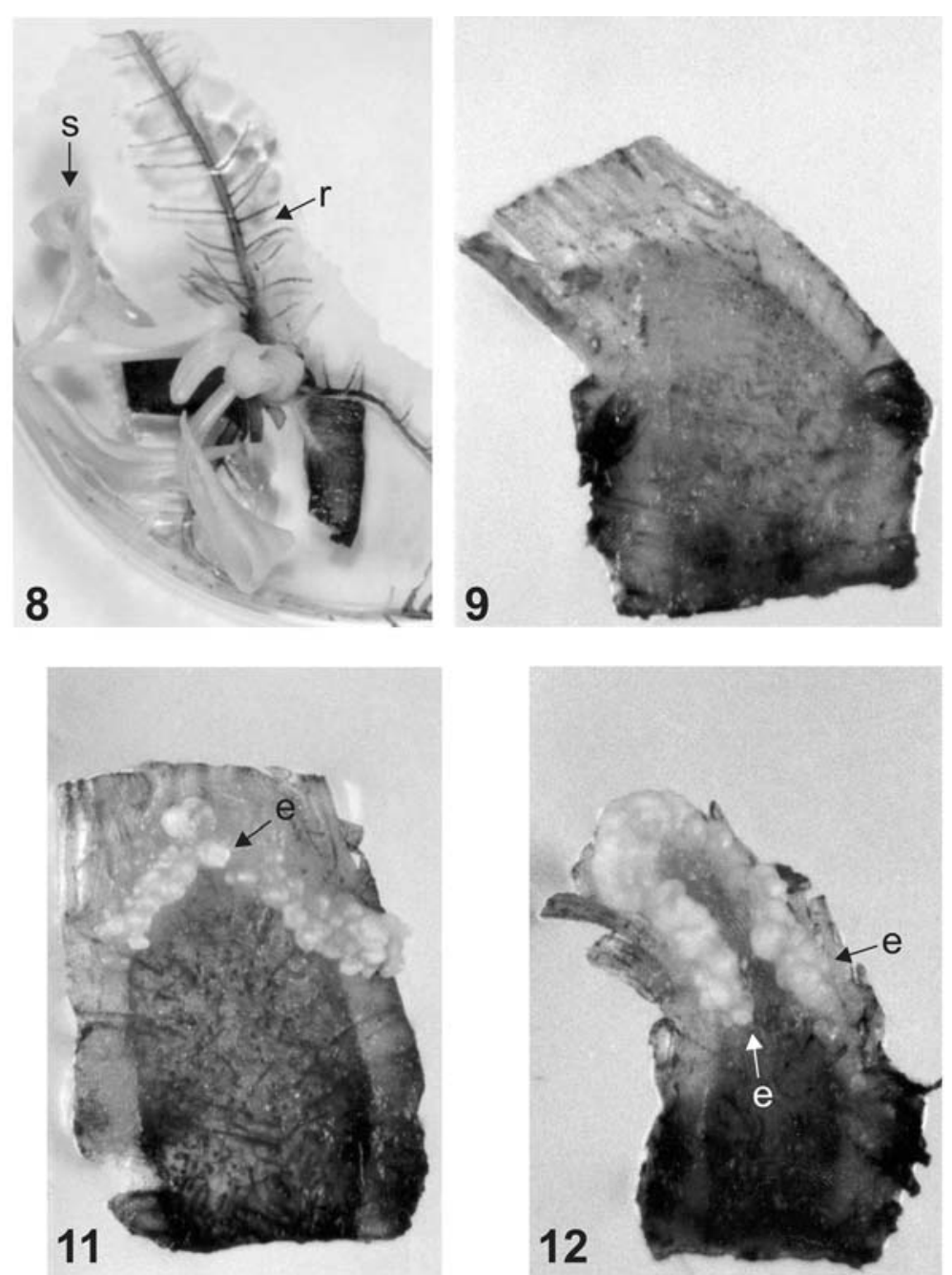

Figures 7-12. Vegetative apex explants of banana, cv. Nanicão, at explanting and after 30 days in MS medium containing different auxins for somatic embryo induction. 7. Longitudinal section of the vegetative apex used as explant. 8. Growth of preexisting buds and roots from the explant in medium containing $20 \mathrm{mM}$. 9-10. Absence of embryogenic response in medium containing $15 \mu \mathrm{M}$ 2,4-D (9) and $20 \mu \mathrm{M}$ 2,4-D (10). 11-12. Formation of embryogenic structures in medium supplemented with $5 \mu \mathrm{M}$ picloram (11), and $10 \mu \mathrm{M}$ dicamba (12). (Base of explant ranges from 5-10 mm). (arrow = leaf base (7), cc $=$ central cylinder, $\mathrm{p}=$ cortical parenchyma, rectangle corresponds to an area similar to those presented in figures $1-6, s=$ shoot buds, $r$ $=$ roots, $\mathrm{e}=$ embryogenic structures). Bars $=2 \mathrm{~mm}(7)$.

compounds. The haustorium region of the zygotic embryo (McGahan 1961) had cells with smaller vacuoles and dense cytoplasm, while somatic embryo cells in the haustorium region showed a large central vacuole, with very reduced cytoplasm. Zygotic embryos had a distinct shoot apical meristem, leaf primordium and vascular strands (McGahan 1961), which are absent in somatic embryos obtained under the conditions of this experiment (figure 17). Lee et al. (1997) observed regions with more intense mitotic activity in banana somatic embryos after 50 days in induction medium, which could be the initial stage of plumule development, however, further embryo development was not observed.

After 30 days in induction medium and transfer to liquid medium without auxin, somatic embryos detached from the explant and initial development 

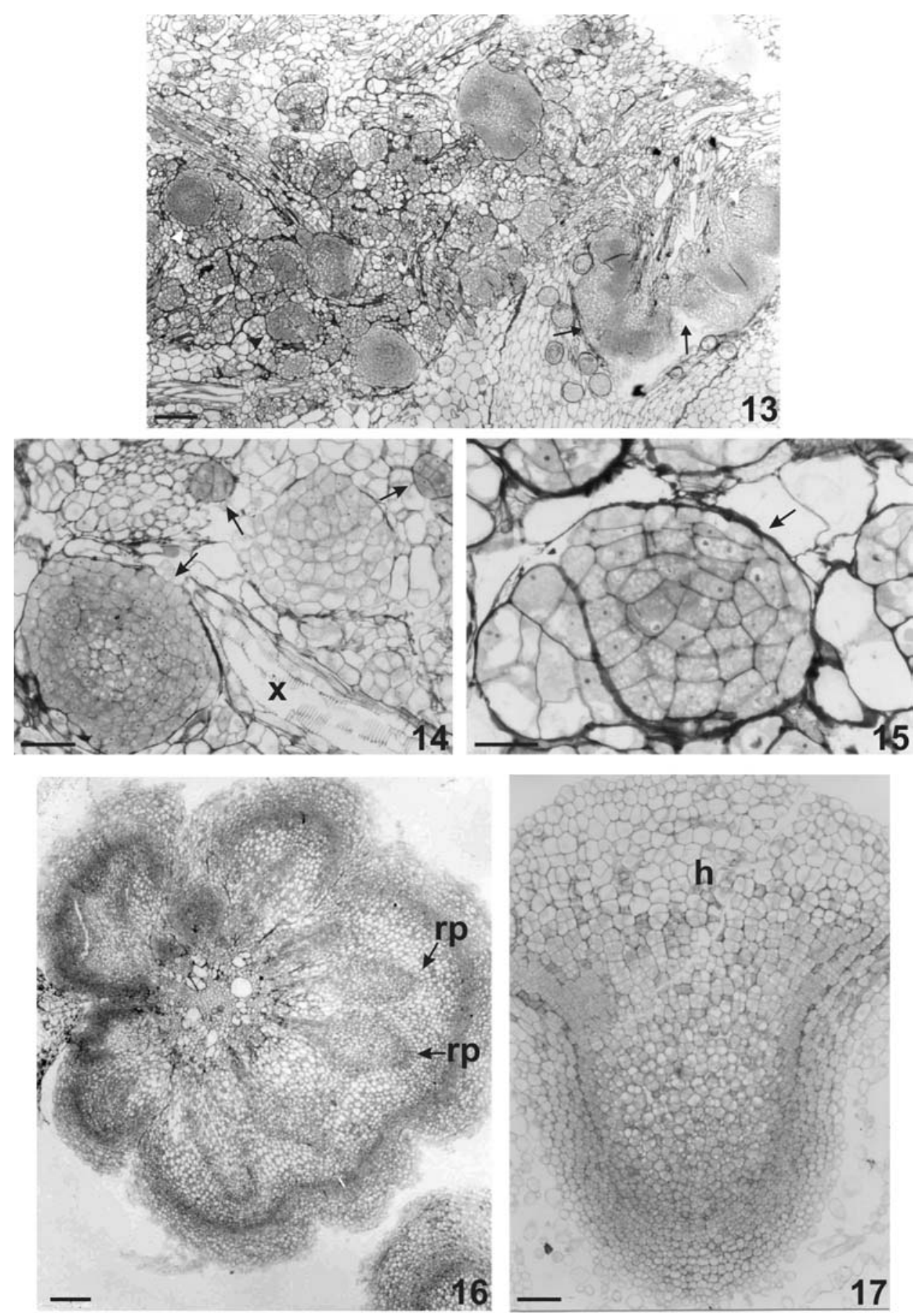

Figures 13 - 17. Longitudinal sections of banana, cv. Nanicão, explants, and somatic embryos 26 days after introduction in MS medium containing $10 \mu \mathrm{M}$ dicamba. 13. Explant region showing both embryogenic regions with proembryo formation (arrowhead) and non-globular meristematic regions, with high mitotic activity (arrows). 14-15. Proembryos (arrows) formed close to xylem tracheary elements (x) (14) and isolated from the neighboring cells by separation of cell walls (15). 16. Structure observed at 34 days in culture showing differentiation of multiple root primordia (rp). 17. Somatic embryos showing absence of histodifferentiation. $(\mathrm{h}=$ haustorium). Bars $=200 \mu \mathrm{m}$ (figures 13 and 16), $50 \mu \mathrm{m}$ (figures 14 and 15), 100 $\mu \mathrm{m}$ (figure 17). 
of a root primordium was observed. However, conversion of these embryos into plants did not occur, probably due to a lack of development of the shoot apical meristem. Similar results were obtained by Lee et al. (1997) with banana somatic embryos, and Nickle \& Yeung (1993) with Daucus carota L..

Fischer \& Neuhaus (1996) observed that the shoot apex development of Triticum aestivum L.. induced in 2,4,5-T was interrupted due to the vacuolization of the cells in the meristem. According to these authors, the establisment of polarity represents the initial stage of development of embryonic structures in monocots: the embryonary axis and the scutellum. Auxin polar transport in the globular embryo is essential for the establishment of polarity (Liu et al. 1993). Polarity can be affected if auxin is evenly distributed in the embryo tissues due to an increase in the auxin endogenous level, which can occur by the application of endogenous auxin through the culture medium (Fischer \& Neuhaus 1996).

One important step of embryogenesis, which establishes the onset of histodifferentiation of the somatic embryo, is the protoderm differentiation (Yeung 1995). In this experiment, the somatic embryos also lacked differentiation of the protoderm (figure 17). The somatic embryo was surrounded by vacuolated, loosely arranged cells. Yeung (1995) mentions observations showing that carrot somatic embryos had their development arrested due to abnormal formation of the protoderm.

More detailed studies should be developed aiming to obtain banana somatic embryos of higher quality, which can efficiently convert into plants. Somatic embryo quality can be improved with optimization of parameters like the type and concentration of plant growth regulators, time in induction medium and maturation treatments. Somatic embryo quality is essential for high somatic embryo conversion rates.

Acknowledgements - To Fapesp (Fundação de Amparo à Pesquisa do Estado de São Paulo) and CNPq (Conselho Nacional de Desenvolvimento e Pesquisa) for the research grant (FAPESP 1995/9553-2) and scholarships (FAPESP and CNPq) for Silvia Balbão Filippi.

\section{References}

COTÊ, F.X., DOMERGUE, R., MONMARson, S., SCHWENDIMAN, J., TEISSON, C. \& ESCALANT, J.V. 1996. Embryogenic cell suspension from the male flower of Musa AAA cv. Grand Nain. Physiologia Plantarum 97:285-290.

DEDH'A, D., DUMORTIER, F., PANIS, B., VUYLSTEKE, D. \& DE LANGUE, E. 1991. Plant regeneration in cell suspension cultures of the cooking banana cv. Bluggoe (Musa spp. ABB group). Fruits 46:125-135.

ESCALANT, J.V., TEISSON, C. \& CÔTE, F.X. 1994. Amplified somatic embryogenesis from male flowers of triploid banana and plantain cultivars (Musa spp.). In vitro Cellular Developmental Biology-Plant 30:181-186.

FEDER, N. \& O'BRIEN, T.P. 1968. Plant microtechnique: some principles and new methods. American Journal of Botany 55:123-142.

FISCHER, C. \& NEUHAUS, G. 1996. Influence of auxin on the establishment of bilateral symmetry in monocots. The Plant Journal 9:659-669.

GRAPIN, A., SCHWENDIMAN, J. \& TEISSON, C. 1996. Somatic embryogenesis in plantain bananas. In vitro Cellular Developmental Biology-Plant 32:66-71.

LAZZERI, P.A., HILDEBRANDT, D.F. \& COLLINS, G.B. 1987. Soybean somatic embryogenesis: effects of hormones and culture manipulations. Plant Cell, Tissue and Organ Culture 10:197-208.

LEE, K.S., ZAPATA-ARIAS, F.J., BRUNNER, H. \& AFZA, R. 1997. Histology of somatic embryo initiation and organogenesis from rhizome explants of Musa spp. Plant Cell, Tissue and Organ Culture 51:1-8.

LEVI, A. \& SINK, K.C. 1991. Histology and morphology of asparagus somatic embryos. HortScience 26:1322-1324.

LIU, C.M., XU, Z.H. \& CHUA, N.H. 1993. Auxin polar transport is essential for the establishment of bilateral symmetry during early plant embryogenesis. Plant Cell 5:621-630.

MCGAHAN, M.W. 1961. Studies on the seed of banana. I. Anatomy of the seed and embryo of Musa balbisiana. American Journal of Botany 48:230-238.

MURASHIGE, T. \& SKOOG, F. 1962. A revised medium for rapid growth and bioassays with tobacco tissue cultures. Physiologia Plantarum 15:473-97.

NICKLE, T.C. \& YEUNG, E.C. 1993. Failure to establish a functional shoot meristem may be a cause of conversion failure in somatic embryos of Daucus carota (Apiaceae). American Journal of Botany 80:1284-1291.

NOVAK, F.J., AFZA, R., VAN DUREN, M., PEREADALLOS, M., CONGER, B.V. \& XIOLANG, T. 1989. Somatic embryogenesis and plant regeneration in suspension cultures of dessert (AA, AAA) and cooking (AAB) bananas. Bio/Technology 46:125-135.

RODRIGUEZ, A.P.M. \& WETZSTEIN, H.Y. 1994. The effect of auxin type and concentration on pecan (Carya illinoinensis) somatic embryo morphology and subsequent conversion into plants. Plant Cell Reports 13:607-611. 
RODRIGUEZ, A.P.M. \& WETZSTEIN, H.Y. 1998. A morphological and histological comparison of the initiation and development of pecan (Carya illinoinensis) somatic embryogenic cultures induced with naphthaleneacetic acid or 2,4-dichlorophenoxyacetic acid. Protoplasma 204:71-83.
WILLIAMS, E.S. \& MAHESWARAN, B. 1986. Somatic embryogenesis: factors influencing coordinated behavior of cells as an embryogenic group. Annals of Botany .57:443-462.

YEUNG, E.C. 1995. Structural and developmental patterns in somatic embryogenesis. In: In vitro embryogenesis in plants(T.A. Thorpe, ed.). Kluwer Academic, Dordrecht, p. 205-247. 